\title{
POLITIK PENDIDIKAN ISLAM DI INDONESIA: Analisis Sistem Pendidikan Pesantren dan Madrasah
}

\section{Supriadin $^{*}$}

\begin{abstract}
Abstrak: Pendidikan Islam merupakan subsistem pendidikan nasional. Kajian ini mengurai realitas pendidikan pesantren dan madrasah; bagaimana sistem pendidikannya dan bagaimana pula kebijakan pemerintah terhadap dua lembaga pendidikan Islam tersebut. Sistem pendidikan pesantren menunjukkan sifat dan bentuk yang berbeda dari pola pendidikan nasional. Maka pesantren menghadapi dilema untuk mengintregasikan sistem pendidikan yang dimiliki dengan sistem pendidikan nasional. Sementara itu, kelahiran madrasah merupakan upaya strategis untuk mengintegrasikan pola pendidikan Islam ala pesantren dengan pola pendidikan modern (ala Barat). Intervensi kebijakan/politik berpengaruh terhadap eksistensi pesantren dan madrasah. Pesantren dan madrasah diniyah sebagai sumber pendidikan dan pencerdasan masyarakat Indonesia yang sudah berurat-akar sejak sebelum kemerdekaan baru mendapatkan pengakuan secara yuridis pada era reformasi.
\end{abstract}

Kata kunci: Pesantren, madrasah, politik pendidikan, pendidikan Islam.

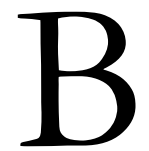

erdasarkan amanat UUD 45 (Pasal 31) setiap rakyat Indonesia berhak mendapatkan pendidikan yang layak, pemerintah selaku pejabat yang dipilih oleh rakyat dibebankan untuk mengusahakan dan menyelenggarakan sistem pendidikan nasional. Guna menjalankan apa yang menjadi amanat UUD 1945, maka pemerintah memberikan kesempatan kepada masyarakat untuk menyelenggarakan pendidikan melalui lembaga pendidikan, yaitu lembaga yang dikelola oleh pemerintah atau

*Penulis adalah Mahasiswa Program Pascasarjana UIN Alauddin Makassar. email: supriadinaljundiyyu@yahoo.co.id 
dikelola oleh swasta (yayasan) namun masih tetap berada dalam koordinasi pemerintah.

Secara yuridis, politik pendidikan di Indonesia dituangkan dalam Undang-undang Sistem Pendidikan. Sampai kini telah diterbitkan 3 (tiga) undang-undang sistem pendidikan nasional, yaitu Undang-Undang Pokok Pendidikan dan Pengajaran No. 4 Tahun 1950 jo Undang-Undang RI No. 12 Tahun 1954 yang diterbitkan pada masa orde lama, Undang-Undang RI No. 2 Tahun 1989 tentang Sistem Pendidikan Nasional pada masa orde baru, dan Undang-undang RI No. 20 Tahun 2003 tentang Sistem Pendidikan Nasional pada masa reformasi yang merupakan perubahan dari undang-undang sistem pendidikan nasional sebelumnya. Pesantren sebagai cikal bakal lembaga pendidikan yang asli Indonesia baru mendapat pengkuan secara yuridis pada tahun 2003 melalui Undang-undang Sisdiknas No. 20 Tahun 2003. Sementara madrasah akhirnya diakui menjadi sub sistem dari sistem pendidikan nasional setelah secara perlahan dan pasti mengurangi dan memarjinalkan pelajaran ilmu-ilmu agama (Anwar, 2010:35).

Dalam konteks ke-Indonesia-an rakyat tidak harus bingung untuk mencari pendidikan, di negeri ini lembaga pendidikan sangat banyak dan beragam, bagi yang beragama Islam, mereka bisa memilih lembaga pendidikan seperti, pondok pesantren dan juga madrasah. Dan juga ada sekolah umum. Ketiga lembaga ini samasama mempunyai peran untuk memberikan ilmu dan memberdayakan masyarakat. Warga diberikan kebebasan untuk memilih lembaga pendidikan yang ada. Memilih sesuai dengan minat dan keinginannya. Bagi orang yang hendak menguasai pendidikan umum mereka bisa memilih jalur pendidikan umum, bagi mereka yang hendak mendalami dan menguasai pendidikan agama, mereka bisa memilih lembaga pendidikan pesantren, dan bagi yang berkeinginan ingin mengerti dan memahami keduaduanya (agama dan umum) bisa mengambil jalur madrasah.

Berangkat dari uraian singkat di atas, maka permasalahan pokok dalam kajian ini adalah bagaimana sistem pendidikan pesantren dan madrasah, selanjutnya masalah pokok tersebut 
El-HiKMAH, Volume 8, Nomor 2, Desember 2014

dijabarkan dalam submasalah berikut; Bagaimana realitas pendidikan di pesantren?; Bagaimana realitas pendidikan di madrasah?, dan bagaimana kebijakan pemerintah terhadap pendidikan pesantren dan madrasah?

\section{Sistem Pendidikan Pesantren}

Perkembangan pendidikan pesantren

Pesantren atau pondok pesantren merupakan lembaga pendidikan Islam tradisional tertua di Indonesia. Pesantren adalah lembaga yang bisa dikatakan merupakan wujud proses wajar perkembangan sistem pendidikan nasional. Sebab, sebelum datangnya Islam ke Indonesia pun lembaga serupa pesantren ini sudah ada di Indonesia dan Islam tinggal meneruskan, melestarikan, dan mengislamkannya. Jadi, pesantren merupakan hasil penyerapan akulturasi kebudayaan Hindu-Budha dan kebudayaan Islam kemudian menjelma menjadi suatu lembaga yang dikenal sebagai pesantren sekarang ini.

Akar-akar historis keberadaan pesantren di Indonesia dapat dilacak jauh ke belakang, yaitu pada masa-masa awal datangnya Islam di bumi Nusantara ini dan tidak diragukan lagi pesantren intens terlibat dalam proses islamisasi tersebut. Sementara proses islamisasi itu, pesantren dengan canggihnya telah melakukan akomodasi dan transformasi sosio-kultural terhadap pola kehidupan masyarakat setempat. Oleh karena itu, dalam prespektif historis, lahirnya pesantren bukan sekedar untuk memenuhi kebutuhan akan pentingnya pendidikan, tetapi juga untuk penyiaran agama Islam. Menurut M. Dawam Raharjo (1985:vii), hal itu menjadi identitas pesantren pada awal pertumbuhannya, yaitu sebagai pusat penyebaran agama Islam, di samping sebagai sebuah lembaga pendidikan.

Pesantren merupakan sistem pendidikan tertua khas Indonesia. Ia merupakan sumber inspirasi yang tidak pernah kering bagi para pencita ilmu dan peneliti yang berupaya mengurai anatominya dari berbagai dimensi. Dari kawahnya, sebagai objek studi telah lahir doktor-doktor dari berbagai disiplin ilmu, mulai dari antropologi, 
sosiologi, pendidikan, politik, agama dan lain sebagainya. Dengan begitu, pesantren dapat dilihat sebagai sistem pendidikan Islam di negeri ini yang kontribusinya tidak kecil bagi pembangunan manusia Indonesia seutuhnya.

Sistem pendidikan di pesantren mengadopsi nilai-nilai yang berkembang di masyarakat. Keadaan ini menurut Abdurrahman Wahid disebut dengan istilah subkultur. Ada tiga elemen yang mampu membentuk pesantren sebagai subkultur: 1) pola kepemimpinan pesantern yang mandiri, tidak terkooptasi oleh negara. 2) kitab-kitab rujukan umum yang selalu digunakan dari berbagai abad. 3) sistem nilai yang digunakan adalah bagian dari masyarakat luas (Wahid, 1999:14). Tiga elemen ini menjadi ciri yang menonjol dalam perkembangan pendidikan di pesantren. Pesantren baru mungkin bermunculan dengan tidak menghilangkan tiga elemen itu, kendati juga membawa elemen-elemen lainnya yang merupakan satu kesatuan dalam sistem pendidikannya.

Secara esensial, sistem pendidikan pesantern yang dianggap khas ternyata bukan sesuatu yang baru jika dibandingkan sistem pendidikan sebelumnya. Masuknya Islam tidak mengubah hakikat pengajaran agama yang formil. Perubahan yang terjadi sejak pengembangan Islam hanyalah menyangkut isi agama yang dipelajari, bahasa yang menjadi wahana bagi pelajaran agama itu, dan latar belakang para santri. Dengan demikian, menurut Nurcholish Madjid (1997:3), sistem pendidikan yang dikembangkan pesantren dalam banyak hal merupakan hasil adaptasi dari poalpola pendidikan yang telah ada dikalangan masyarakat HinduBudha sebelumnya. Jika ini benar, ada relevansinya dengan statement bahwa pesantren mendapat pengaruh dari tradisi lokal.

Proses adaptasi sistem pendidikan itulah yang menguatkan penilaian selama ini bahwa pendidikan pesantren disebut sisten pendidikan produk Indonesia. Nurcholish Madjid (1997:3) menyebut dengan istilah indegenous (pendidikan asli Indonesia). Sistem pendidikan asli Indonesia ini pernah menganut dan memiliki daya tawar yang tinggi sebagai antitesis terhadap sistem pendidikan Belanda. Karel A. Streenbrink (1994:212) mengungkapkan bahwa 
El-HiKMAH, Volume 8, Nomor 2, Desember 2014

pada 1930-an, sistem pesantren yang sering disebut sistem pendidikan asli Indonesia dapat menyaingi pendidikan Barat yang materialis dan bertujuan mempersiapkan tenaga untuk fungsi-fungsi tertentu dalam masyarakat dan untuk mencari uang.

Selanjutnya pesantern adalah sistem pendidikan yang melakukan kegiatan sepanjang hari. Santri tinggal di asrama dalam satu kawasan bersama guru, kiai dan senior mereka. Oleh karena itu, hubungan yang terjalin antara santri-guru-kiai dalam proses pendidikan berjalan intensif, tidak sekedar hubungan formal ustadsantri di dalam kelas. Dengan demikian kegiatan pendidikan berlangsung sepanjang hari, dari pagi hingga malam hari.

Sistem pendidikan ini membawa keuntungan, antara lain: pengasuh mampu melakukan pemantauan secara leluasa hampir setiap saat terdapat perilaku santri baik yang terkait dengan upaya pengembangan intelektualnya maupun kepribadiannya. Keuntungan kedua adalah adanya proses pembelajaran dengan frekuensi yang tinggi dapat memperkokoh pengetahuan yang diterimanya. Dalam teori pendidikan diakui bahwa belajar satu jam yang dilakukan lima kali lebih baik daripada belajar selama lima jam yang dilakukan sekali, padahal rentangan waktunya sama. Keuntungan ketiga adalah adanya proses pembiasaan akibat interaksinya setiap saat baik sesama santri, santri denga ustad maupun santri dengan kiai. Keuntungan lainnya adalah adanya integrasi antara proses pembelajaran dengan kehidupan keseharian. Mastuhu (1994:58) menilai bahwa sistem pendidikan pesantren menggunakan pendekatan holistik. Para pengasuh memandang kegiatan belajar mengajar merupakan kesatupaduan atau lebur dalam totalitas kegiatan kehidupan sehari-hari. Akibatnya muncul sikap saling menjaga komitmen dan konsistensi terutama dari pihak pengasuh baik kiai maupun ustad. Apa yang dianjurkan oleh kiai maupun ustad harus terlebih dahulu terefleksi dalam kehidupan keseharian mereka.

Sistem pendidikan pesantren memang menunjukkan sifat dan bentuk yang lain dari pola pendidikan nasional. Maka pesantren menghadapi dilema untuk mengintregasikan sistem pendidikan 
yang dimiliki dengan sistem pendidikan nasional. Ditinjau dari awal mula sejarah berdirinya pesantren memang tidak dimaksudkan untuk meleburkan dalam sistem pendidikan nasional. Bahkan ketika menghadapi penjajah Belanda, pesantren memiliki strategi isolasi dan konservasi.

Sistem pendidikan pesantren juga sangat bergantung pada selera kiainya. Keahlian dan pengalaman kiai tentu saja turut mewarnai sistem pendidikan pesantren yang diasuhnya. Tidak sedikit spesialisasi pengkajian di pesantren disesuaikan dengan spesialisasi keilmuan yang dimiliki kiainya. Pilihan ini masih dalam batas kewajaran atau keniscayaan, yang menarik justru sikap independen kiai dalam menetukan corak sistem pendidikan pesantrennya.

Kuatnya independensi tersebut menyebabkan pesantren memiliki kebebasan relatif yang tidak harus mengikuti model baku yang ditetapkan pemerintah dalam bidang pendidikan. Pesantren bebas mengembangkan model pendidikannya tanpa harus mengikuti standardisasi dan kurikulum yang ketat (Mastuhu, 1994:64). Pesantren selalu memberikan kebebasan dalam menentukan pola kebijakan pendidikannya. Maka pesantren menggunakan prinsip kebebasan terpimpin dalam menjalankan kebijaksanaan pendidikannya.

Kebebasan terpimpin di sini adalah kebebasan dalam memilih, memutuskan dan menjalankan kebijakan pendidikan sesuai dengan kehendak kiainya. Terhadap kebijakan pemerintah, sistem pendidikan pesantren menempuh sikap sebebas-bebasnya, namun dikalangan intern pesantren sendiri, yang memiliki kebebasan adalah kiainya. Para ustad tidak berkenan menentukan kebijakan pendidikan pesantren, terlebih para santri.

Sehingga, di dalam pesantren tradisional tidak dikenal sistem kelas. Kemampuan siswa tidak dilihat kelas berapanya, tetapi dilihat dari kitab apa yang dibacanya. Orang-orang pesantren telah dapat mendudukan derajat ilmu seorang santri atas dasar kitab yang dibacanya (Daulay, 2001:10). Misalnya, seorang santri telah ikut mengkaji kitab Ihya' Ulüm al-Din maka ia dianggap memilki 
kemampuan yang cukup tinggi karena peserta pengkajian kitab tersebut dari kalangan santri senior, yang tentu terbatas sekali.

Perbedaan lainnya antara pesantren dengan pendidikan formal adalah kesuksesan belajar santri. Jika ada santri yang belajar di pesantren hingga 27 tahun, maka penilaian orang berarti dia memiliki kemampuan yang tinggi. Sebaliknya di perguruan tinggi, kalau ada seorang mahasiswa yang menyelesaikan program S-1 dalam waktu 3 tahun berarti hebat. Jika sampai membutuhkan waktu 10 tahun untuk S-1 berarti mengalami kelambanan serius.

Eksistensi pesantren ternyata sampai hari ini, ditengah-tengah deru modernisasi, pesantren tetap bisa bertahan (survive) dengan identitasnya sendiri. Bahkan akhir-akhir ini para pengamat dan praktisi pendidikan dikejutkan dengan tumbuh dan berkembangnya lembaga-lembaga pedidikan pondok pesantren di tanah air ini. Pertumbuhan pesantren yang semula rural based institution menjadi juga lembaga pendidikan urban, bermunculan juga di kotakota besar. Di samping banyak juga pendidikan umum yang mengadopsi aspek-aspek tertentu dari sistem pendidikan pesantren. Mengadopsi sistem asrama dengan menyebutnya "boarding school". Sistem "boarding” tentu saja merupakan salah satu karakteristik dasar sistem pendidikan pesantren

Satu hal lagi yang perlu dicatat bahwa tidak sedikit pemimpinpemimpin bangsa ini, baik pemimpin yang duduk dalam pemerintahan maupun non-pemerintahan, formal atau informal, adalah figur-figur yang terlahir dari rahim pondok pesantren.

\section{Metode pembelajaran pesantren}

Sebagaimana halnya kurikulum, proses pembelajaran madrasah atau sekolah yang diselenggarakan oleh pondok pesantren juga menggunakan metode pembelajaran yang sama dengan metode pembelajaran di madrasah atau sekolah lain, di luar pondok pesantren. Metode pembelajaran yang digunakan di lembaga pendidikan formal lain yang diselenggarakan oleh pondok pesantren, selain madrasah dan sekolah, pada umumnya mengikuti metode yang berkembang di madrasah atau sekolah. 
Proses pembelajaran di pondok pesantren ada yang menggunakan metode yang bersifat tradisional, yaitu metode pembelajaran yang diselenggarakan menurut kebiasaan yang telah lama dilaksanakan pada pesantren atau dapat juga disebut sebagai metode pembelajan asli (original) pondok pesantren. Di samping itu ada pula yang menggunakan metode pembelajaran modern (tajdid). Metode pembelajaran modern merupakan metode pembelajaran hasil pembaharuan kalangan pondok pesantren dengan memasukkan metode yang berkembang pada masyarakat modern, sesuai dengan pergeseran dan perkembangan kelembagaan maupun kurikulum pendidikan (Qomar, t.th.: 141-142).

Menurut pandangan Kiai Zarkasyi, pendiri pondok pesantren Gontor (Haedari, 2004:40-41), "metode pembelajaran di pesantren merupakan hal yang setiap kali mengalami perkembangandan perubahan sesuai dengan penemuan metode yang lebih efektif dan efisien untuk mengajarkan cabang-cabang ilmu pengetahuan. Meskipun demikian, menurutnya, dalam rentang waktu yang panjang pesantren secara seragam mempergunakan metode yang telah lazim, sorogan dan bandongan (weton)."

Pertumbuhan dan perkembangan pesantren hingga kini, melahirkan pengategorisasian pesantren dalam dua tipe, yaitu tradisional dan modern. Kategori pesantren tersebut berimplikasi pula pada perubahan metode pembelajaran yang bersifat tradisional dan bersifat modern. Menurut Qomar (t.th.:142), mengutip laporan Departemen Agama RI, bahwa metode penyampaian di pesantren ada yang bersifat tradisional (mengikuti kebiasaan-kebiasan yang lama), dan ada pula yang menggunakan metode baru yang diintrodusir ke dalam institusi tersebut berdasarkan pendekatan ilmiah.

Adapun deskripsi secara umum dari beberapa metode pembelajaran di pesantren tersebut dapat diuraikan sebagai berikut; a. Metode Sorogan

Sorogan adalah metode belajar yang berbeda dengan metode bandongan. Dalam metode sorogan, murid membaca kitab kuning dan memberi makna, sementara guru mendengarkan sambil memberi 
catatan, komentar atau bimbingan bila diperlukan. Akan tetapi dalam metode ini, dialog antara guru dengan murid belum atau tidak terjadi. Metode ini tepat bila diberikan kepada murid-murid seusia ibtidaiyah/dasar dan tsanawiyyah/menengah. Menurut M. Ridlwan Nasir (2005:110-111) mengutip pendapat Chirzin mengatakan, istilah sorogan berasal dari kata sorog (Jawa) yang berarti mengajukan/menyodorkan. Tata caranya adalah seorang santri menyodorkan sebuah kitab di hadapan kiai atau pembantu kiai, kemudian kiai memberikan tuntunan bagaimana cara membacanya dan menghafalkannya.

Dalam tradisi pembelajaran pesantren, biasanya yang menjadi sasaran metode sorogan adalah kelompok santri tingkat rendah atau pemula yang baru menguasai pembacaan al-Qur'an. Dengan memnggunakan metode ini, kemajuan intelektual sisa dapat dideteksi secara utuh oleh pendidik. Namun dalam sudut pandang yang lain, penggunaan metode sorogan membutuhkan kesabaran ekstra, serta memerlukan waktu yang relatif lama. Sehingga dari aspek waktu sebagian kalangan menilainya pemborosan serta kurang efektif dan efisien (Qomar, t.th.:142).

Menurut pandangan Nasir, sekalipun metode sorogan ini dinilai kurang efektif oleh sebagian kalangan, namun sistem ini tetap dipertahankan oleh pondok-pondok pesantren karenadilihat banyak manfaat dan faedah yang mendorong santri lebih giat dalam mengkaji kitab-kitab kuning yang memiliki nilai tinggi dalam kehidupan manusia (Nasir, 2005:112).

Menilik konsepsi beberapa pakar di atas, penulis berpandangan bahwa jika disinkronisasikan dengan metode pembelajaran masa kini, metode pembelajaran sorogan ini memiliki paralelisasi dengan metode tutorship atau menthorship, dimana dalam metode tersebut peserta didik memiliki kesempatan untuk melakukan tanya jawab atau sharing dengan gurunya. Sehingga menurut penulis metode ini cukup intensif untuk pengembangan intelektual peserta didik.

b. Bandongan atau Weton

Bandongan atau biasa disebut metode wetonan adalah cara penyampaian kitab kuning di mana seorang guru, kiai atau ustad 
membacakan dan menjelaskan isi kitab kuning. Menurut Zamakhsyari Dhofier (selanjutnya disebut Dhofier) sebagaimana dikutip Qomar (t.th.:143), "metode wetonan atau bandongan merupkaan metode pengajaran dengan cara guru membaca, menerjemahkan, menerangkan dan mengulas buku-buku Arab sementara santri, murid atau siswa mendengarkan, memberi makna dan menerima wejangan."

Melalui metode ini, guru berperan aktif, sementara murid bersifat pasif. Metode bandongan atau weton dapat bermanfaat ketika kelompok jumlah murid cukup besar dan waktu yang tersedia relatif sedikit, sementara materi yang disampaikan cukup banyak. Kelompok kelas dari sistem bandongan ini disebut dengan balaqah (lingkaran murid), sekelompok yang belajar di bawah bimbingan guru (Haedari, dkk., 2004:42).

Dalam sistem bandongan seorang murid tidak harus menunjukkan bahwa ia mengerti terhadp pelajaran yang dihadapi. Kebiasaan para kiai adalah membaca dan menerjemahkan secara cepat teks kitab klasik yang dipeleajari serta meninggalkan kata-kata yang mudah dipahami untuk tidak diterjemahkan. Dengan ara tersebut kiai mampu menyelesaikan kitab dalam waktu yang singkat.

Dengan memahami proses pembelajaran metode bandongan ini dapat ditarik kesimpulan bahwa pembelajaran dengan metode bandongan hanya bisa diaplikasikan pada peserta didik kelas menemgah dan tinggi.

c. Hafalan

Hafalan adalah sebuah metode pembelajaran yang mengharuskan murid mampu menghafal naskah atau syair-syair dengan tanpa melihat teks yang disaksikan oleh guru. Metode ini cukup relevan untuk diberikan kepada murid-murid usia anak-anak, tingkat dasar dan tingkat menengah. Karena menghafal sama dengan mengajak otak agar tetap bekerja. Jika diibaratkan pisau agar tidak cepat tumpul, maka harus sering diasah. Begitupun dengan otak manusia. Agar tidak mudah hilang hafalannya juga harus sering diasah. 
El-HiKMAH, Volume 8, Nomor 2, Desember 2014

\section{d. Diskusi (Munādarah)}

Metode ini sebagai penyajian bahan pelajaran dengan cara murid atau santri membahasnya bersama-sama melalui tukar pendapat tentang suatu topik atau masalah tertentu yang ada dalam kitab kuning atau pelajaran lainnya. Dalam metode ini, kiai atau guru bertindak sebagai moderator karena metode diskusi bertujuan agar murid atau santri aktif dalam belajar. Melalui diskusi ini, akan tumbuh dan berkembang pemikiran-pemikiran kritis, analitis dan logis.

Beberapa metode yang penulis sebutkan di atas, tentunya hanya merupakan representasi secara umum dari metode pembelajaran di pesantren. Namun, seiring berkembangnya dinamika pendidikan maupun teknologi dan informasi, tentunya metode pembelajaran pesantren pun sedemikian rupa menyesuaikan diri dengan perubahan tersebut.

\section{Sistem Pendidikan Madrasah}

\section{Sekilas sejarah labir dan perkembangan madrasah}

Kehadiran lembaga pendidikan Islam di Nusantara tidak lama berselang setelah masuk dan tersebarnya Islam, justru proses Islamisasi diperkuat oleh lembaga pendidikan sebagai medianya (Daulay, 2007:14-15). Menurut Maksum, tidak diketahui pasti sejak kapan madrasah sebagai istilah atau sebutan untuk satu jenis pendidikan Islam digunakan di Indonesia. Namun demikian, madrasah sebagai satu sistem pendidikan Islam ber-kelas dan mengajarkan sekaligus ilmu-ilmu keagamaan dan non keagamaan sudah tampak sejak awal abad 20. Meskipun sebagian di antara lembaga-lembaga pendidikan itu menggunakan istilah school (sekolah), tetapi dilihat dari sistem pendidikannya yang terpadu, lembaga pendidikan seperti itu biasa dikategorikan dalam bentuk madrasah (Maksum, 1999:97).

Latar belakang kelahiran madrasah sendiri bertumpu pada dua faktor penting: (1) pendidikan Islam tradisional kurang sistematis dan kurang memberikan kemampuan pragmatis yang memadai, dan (2) laju perkembangan sekolah-sekolah model Belanda di kalangan 
masyarakat cenderung meluas dan membawa watak sekularisme sehingga harus diimbangi dengan sistem pendidikan Islam yang memiliki model dan organisasi yang lebih teratur dan terencana (Maksum, 1999:114).

Madrasah tidak lahir secara instan, melainkan ia bagian dari pembaruan pendidikan sistem pendidikan sebelumnya, seperti maktab, kuttâh, istana, kedai buku, shuffah, halaqah, masjid, khân, ribâth, toko buku dan perpustakaan. Sedangkan di Indonesia madrasah merupakan bagian dari pembaruan pendidikan sistem pendidikan masjid, pesantren (Madjid, 1997:135), meunasah, rangkang, dayah, dayah teuku cik dan surau.

Mempertegas pendapat Nurcholis Madjid di atas, menurut Muhaimin dalam Hasbullah (1995:163), bahwa:

Kehadiran madrasah sebagai lembaga pendidikan Islam dilatar belakangi oleh empat hal, yaitu; a) sebagai manifestasi dan realisasi pembaharuan pendidikan Islam; b) usaha penyempurnaan terhadap sistem pesantrenke arah suatu sistem pendidikan yang lebih memungkinkan lulusannya memperoleh kesempatan yang sama dengan sekolah umum; c) adanya sikap mental pada sementara golongan ummat Islam, khususnya santri yang terpukau pada Barat sebagai pendidikan mereka; d) sebgaai upaya menjembatani antara sistem pendidikan tradisional yang dilakukan oleh pesantren dan sistem pendidikan modern.

Sementara dalam perspektif yang berbeda, Maksum menjabarkan bahwa latar belakang kelahiran madrasah sendiri bertumpu pada dua faktor penting: (1) pendidikan Islam tradisional kurang sistematis dan kurang memberikan kemampuan pragmatis yang memadai, dan (2) laju perkembangan sekolah-sekolah model Belanda di kalangan masyarakat cenderung meluas dan membawa watak sekularisme sehingga harus diimbangi dengan sistem pendidikan Islam yang memiliki model dan organisasi yang lebih teratur dan terencana(Maksum, 1999:114).

Baik masjid, pesantren, surau, dayah, rangkang dan meunasah tidak memiliki perbedaan yang berarti sebagai sebuah sistem pendidikan. Perbedaannya adalah keragaman, kekayaan dan elastisitas pendidikan Islam. Islam nyaris menjadikan pranatapranata di Nusantara yang telah berlaku di komunitas setempat 
El-HiKMAH, Volume 8, Nomor 2, Desember 2014

sebagai basis penyiaran Islam, agar dapat dengan mudah diterima oleh masyarakat setempat, yang kemudian diislamisasikan (Azra, 2002).

Berangkat dari beberapa pandangan tersebut, menurut hemat penulis kelahiran madrasah merupakan upaya strategis untuk mengintegrasikan pola pendidikan Islam ala pesantren dengan pola pendidikan modern (ala Barat). Sekaligus sebagai upaya meminimalisir ummat Islam Indonesia dari keterpurukan dalam sistem pendidikan (dengan hanya mengandalkan sistem pendidikan tradisional), yang muaranya juga berimplikasi pada lapangan pekerjaan para alumnus lembaga pendidikan tersebut.

Kemunculan madrasah di awal abad ke-20 disebut sebagai awal pembaruan sistem pendidikan Islam. Di mana pendidikan pra madrasah tidak mengenal sistem klasikal dengan meja, bangku dan papan tulis sebagai sarana pembelajaran. Meskipun demikian, pesantren dan madrasah memiliki kesamaan yang mendasar, yaitu sama-sama mengajarkan ilmu-ilmu Islam dan kehadiran madrasah merupakan akibat penyesuaian dengan pesantren (Steenbrink, 1994:2-3).

Pada tahun 1909 Syekh Abdullah Ahmad mendirikan Adabiah School (Sekolah Adabiyah) sebagai madrasah pertama. Adabiab School sebagai madrasah bertahan hingga tahun 1914, kemudian berubah menjadi H.I.S Adabiah pada tahun 1915 dimana pelajaran agama hanya sebagai pelengkap dalam pembelajaran di H.I.S. Dengan demikian H.I.S Adabiah merupakan H.I.S pertama di Minangkabau yang memasukkan pelajaran agama Islam bagi para peserta didiknya (Yunus, 1996:63).

Pada tahun yang sama, Syekh M. Thaib Umar mendirikan Madras School di Batusangkar, namun madrasah ini tidak bertahan lama. Tepat pada tahun 1913 Madras School ditutup karena alasan keterbatasan tempat, akan tetapi Mahmud Yunus membangun kembali Madrasah ini pada tahun 1923 dengan nama Diniah School dan diganti kembali namanya dengan Al Jami'ah Islamiah pada tahun 1931. Setahun kemudian, yakni pada tahun 1915 Zainuddin Labai al-Junusi mendirikan Diniah School di Padangpanjang, 
dimana madrasah ini mendapat sambutan yang hangat di kalangan masyarakat Minangkabau dan Indonesia (Yunus, 1996:63-66).

Tidak ketinggalan, pulau Jawa pun mengikuti pembaharuan lembaga pendidikan Islam yang telah dilakukan di tanah Minang. KH Hasyim Asy'ari, misalnya, pada tahun 1916 mendirikan Madrasah Salafiah dalam pesantren salafiah yang ia dirikan juga di Tebuireng dengan sistem klasikal (Steenbrink, 1994:70). Akan tetapi madrasah di Jakarta merupakan madrasah pertama di pulau Jawa yang didirikan oleh al-Jāmi’at al-Khairiyah, sebuah organisasi yang sangat memperhatikan bidang pendidikan mulai dari pendiriannya pada tahun 1905. Madrasah yang didirikan organisasi ini tidak hanya mempelajari ilmu-ilmu agama saja melainkan juga ilmu-ilmu umum, seperti berhitung, sejarah dan ilmu bumi. Meskipun mayoritas anggota organisasi ini keturunan Arab, bahasa Melayu tetap menjadi bahasa pengantar dalam kegiatan belajar mengajarnya. Karena madrasah ini tidak hanya diperuntukkan untuk anak-anak keturunan Arab melainkan juga anak-anak asli pribumi (Zuhairini, dkk, 1997:159-160).

Para pengajarnya pun didatangkan dari daerah-daerah Indonesia di samping dari Arab. Muhammad Mansur merupakan pengajar yang didatangkan dari Padang pada tahun 1907 karena keahliannya dalam ilmu-ilmu keislaman dan bahasa Melayu. Mulai tahun 1911 organisasi ini mendatangkan pengajar-pengajar dari negeri-negeri Arab, seperti al-Hasyimi dari Tunis, Syekh Ahmad Surkati dari Sudan, Syekh Taib dari Maroko dan Syekh Muhammad Abdul Hamid dari Makkah.Dua tahun berikutnya, yakni tahun 1913 organisasi ini mendatangkan lagi guru-guru lulusan al-Azhar, antara lain Abdul Fadal Ansari, Muhammad Noor al Ansari, Hasan Hamid al Antasari dan Ahmad al Awif (Zuhairini, dkk, 1997:160).

Pada tahun 1915 berdiri pula madrasah di Jakarta atas prakarsa Al Irsyad, dimana para pengajar awalnya mengajar di madrasah yang didirikan oleh Jami'at Khair. Tidak ketinggalan, pada tahun 1916 Perserikatan Ulama mendirikan madrasah di Tanah Sunda dengan nama Jam'iyat I'anat al Muta'allimin dengan KH Halim 
sebagai pendirinya sekaligus sebagai direkturnya (Zulhanda dalam Nizar [ed.], 2013:356).

Tidak ketinggalan Muhammadiyah, organisasi yang berdiri pada tahun 1912, sangat meperhatikan lembaga pendidikan dalam pergerakkannya. Sejak berdirinya, organisasi ini telah mendirikan madrasah-madrasah baik di kota dimana organisasi ini dicetuskan dan diresmikan maupun di seluruh kepulauan Indonesia. Tidak mengherankan jika terdapat madrasah-madrasah Muhammadiyah yang historis dan memiliki kontribusi dalam perjalanan bangsa Indonesia, madrasah tersebut antara lain: Kweekschool Muhammadiyah, Mu'allimin Muhammadiyah, Mu'allimat Muhammadiyah, Zu'ama' dan Za'imat, Kulliyah Muballighin dan Muballighat, Tablighschool dan H.I.K Muhammadiyah (Yunus, 1996:268-269).

Bertolak dari deskripsi di atas, tidak dapat dipungkiri bahwa madrasah merupakan hasil perjalanan keilmuan dan pendidikan yang amat panjang di Nusantara bahkan di berbagai belahan dunia yang didiami oleh kaum muslimin. Meski demikian, peran masjid ataupun lembaga pendidikan Islam tradisional tetap berjalan dan berkembang meski tidak menjadi trend ataupun mainstream sistem pendidikan.

\section{Sistem pendidikan dan pengajaran madrasah}

Sistem pendidikan di madrasah merupakan perpaduan sistem pondok pesantren dengan sistem pendidikan yang berlaku di pesantren. Sistem pembelajaran tersebut berlangsung secara bertahap, dengan mengikuti sistem klasikal. Sistem pengajian kitab dalam tradisi pesantren mulai diganti dengan bidang-bidang pelajaran tertentu, sekalipun masih menggunakan kitab lama (Hasbullah, 1995:170). 
Politik Pendidikan Islam... (Supriadin)

\section{Kebijakan Pemerintah Terhadap Pendidikan Islam (Pesantren dan Madrasah)}

Pesantren dan madrasah pada masa orde lama dan orde baru

Pada masa Orde Lama pesantren dan madrasah bukan hanya mendapat pengakuan, tetapi juga dukungan dalam bentuk pembinaan dan tuntunan. Wewenang untuk melakukan pembinaan terhadap pesantren dan madrasah itu kemudian diserahkan kepada Departemen Agama.

Dalam rangka meningkatkan madrasah sesuai dengan saran BPKNIP, Kementerian Agama mengeluarkan Peraturan Menteri Agama No. 1 Tahun 1946, dan kemudian disempurnakan dengan Peraturan Menteri Agama No. 7 Tahun 1952, yang mengatur tentang jenjang pendidikan pada madrasah. Menurut peraturan ini, jenjang pendidikan pada madrasah terdiri dari:

1. Madrasah Rendah (sekarang disebut Madrasah Ibtidaiyah), yaitu madrasah yang memuat pendidikan dan ilmu pengetahuan agama Islam sebagai pokok pengajarannya, lama pendidikan 6 tahun.

2. Madrasah Lanjutan Tingkat Pertama (sekarang disebut Madrasah Tsanawiyah), ialah madrasah yang menerima muridmurid tamatan Madrasah Rendah atau yang sederajat, serta memberi pendidikan dalam ilmu pengetahuan agama Islam sebagai pokok pengajarannya, lama pendidikan 3 tahun.

3. Madrasah Lanjutan Atas (sekarang disebut Madrasah Aliyah), ialah madrasah yang menerima murid-murid tamatan Madrasah Lanjutan Pertama atau yang sederajat, serta memberi pendidikan dalam ilmu pengetahuan agama Islam sebagai pokok pengajarannya, lama belajar 3 tahun.

Upaya peningkatan mutu madrasah juga dilakukan dengan meningkatkan status madrasah-madrasah yang dikelola oleh masyarakat, baik pribadi maupun organisasi, dari swasta menjadi negeri. Madrasah-madrasah yang dinegrikan itu mulai tingkat dasar yang diberi nama Madrasah Ibtidaiyah Negeri (MIN), tingkat lanjutan pertama diberi nama Madrasah Tsanawiyah Agama Islam Negeri (MTsAIN), dan tingkat atas diberi nama Madrasah Aliyah 
El-HiKMAH, Volume 8, Nomor 2, Desember 2014

Agama Islam Negeri (MAAIN) (Hasbullah, 1995:176). Selain itu, pesantren juga menerima perubahan status madrasahnya menjadi madrasah negeri karena dianggap sangat menguntungkan dari segi keuangan pesantren. Pesantren tidak lagi terlalu banyak menyandarkan diri kepada pemasukan dari para santri atau pun sedekah dari masyarakat untuk menggaji para gurunya (Madjid, 1997:82).

Sementara pada masa pemerintahan orde baru, kebijakan dalam beberapa hal mengenai madrasah bersifat melanjutkan dan memperkuat kebijakan orde lama. Pada tahap ini madrasah belum dilihat sebagai bagian dari sistem pendidikan secara nasional, tetapi merupakan lembaga pendidikan otonom di bawah pengawasan Menteri Agama. Hal ini disebabkan karena kenyataan bahwa sistem pendidikan madrasah lebih didominasi oleh muatan-muatan agama, menggunakan kurikulum yang belum terstandar, memiliki struktur yang tidak seragam, dan memberlakukan managemen yang kurang dapat dikontrol oleh pemerintah (Maksum, 1997:132).

Selain itu menurut pengamatan pemerintahan orde baru bahwa program Madrasah Wajib Belajar berjalan kurang sesuai dengan harapan sehingga Kementerian Agama terus menata kurikulum pendidikan madrasah sejalan dengan tuntutan pendidikan nasional. Sebagai efek dari Ketetapan MPRS No. XXVII/1966, pada tahun 1967 Menteri Agama mengeluarkan kebijakan untuk menegerikan sejumlah madrasah dalam semua tingkatan mulai dari tingkat Ibtidaiyah sampai dengan Aliyah. Melalui usaha ini sebanyak 123 Madrasah Ibtidaiyah telah dinegerikan sehingga menambah jumlah total Madrasah Ibtidaiyah Negeri (MIN) menjadi 358. Dalam waktu yang bersamaan, juga telah berdiri sekitar 182 Madrasah Tsanawiyah Negeri dan 42 Madrasah Aliha Agama Islam Negeri (MAAIN). Dengan memberikan status negeri ini, tanggung jawab pengelolaan memang menjadi beban pemerintah, tetapi pengaturan dan kontrol atas madrasah-madrasah itu menjadi lebih efektif (Maksum, 1997:141).

Perkembangan berikutnya menurut Maksum, antara akhir 70an sampai dengan akhir 80-an, pemerintah orde baru mulai 
memikirkan kemungkinan mengintegrasikan madrasah ke dalam Sistem Pendidikan Nasional. Usaha menuju ke arah ini agaknya tidak sederhana karena secara konstitusional pendidikan nasional masih diatur oleh UU No. 4 tahun 1950 jo No. 12 Tahun 1954 yang mengabaikan pendidikan madrasah. Apa yang bisa dilakukan pemerintah pada tahap ini adalah memperkuat struktur madrasah baik dalam jenjang maupun kurikulumnya- sehingga lulusannya memperoleh pengakuan yang sama dengan lulusan dan dapat melanjutkan ke jenjang pendidikan yang lebih tinggi di sekolahsekolah yang dikelola Departemen Pendidikan dan Kebudayaan. Untuk tujuan ini dikeluarkan kebijakan berupa Surat Keputusan Bersama (SKB) Tiga Menteri pada tahun 1975 tentang peningkatan mutu pendidikan pada madrasah (Maksum, 1997).

Menurut Daulay, inti dari SKB tersebut adalah upaya untuk meningkatkan mutu madrasah, dalam surat keputusan tersebut dicantumkan (Daulay, 2004:152):

a. Ijazah madrasah dapat mempunyai nilai yang sama dengan ijazah sekolah umum yang setingkat.

b. Lulusan madrasah dapat melanjutkan ke sekolah umum yang setingkat lebih di atasnya.

c. Siswa madrasah dapat berpindah ke sekolah umum yang setingkat (SKB Tiga Menteri Tahun 1975, Bab II, Pasal 2).

Dengan dilaksanakannya SKB Tiga Menteri ini berarti:

1) Eksistensi madrasah sebagai lembaga pendidikan Islam lebih mantap dan kuat.

2) Pengetahuan umum pada madrasah-madrasah lebih meningkat.

3) Fasilitas fisik dan peralatan lebih disempurnakan.

4) Adanya civil effect terhadap ijazah madrasah.

Pada masa Menteri Munawir Sjadzali, didirikanlah Madrasah Aliyah Program Khusus. Madrasah ini diharapkan menjadi lembaga mencetak calon ulama yang mengerti agama dengan baik juga pengetahuan umum, utamanya bahasa Arab dan Inggris. Namun sayangnya, MAPK/MAK ini tidak mempunyai payung hukum, karena madrasah yang diakui berdasarkan SKB Tiga Menteri itu adalah $70 \%$ pelajaran umum dan 30\% pelajaran agama (Hasbulloh, 
El-HiKMAH, Volume 8, Nomor 2, Desember 2014

1995:185-186). Bahkan, madrasah ini juga belum jelas posisinya dalam UU Sisdiknas No. 2 Tahun 1989. MAPK/MAK, termasuk di dalam pendidikan keagamaan, baru mendapat tempat dalam UU Sisdiknas No. 20 Tahun 2003.

Pada dasarnya, dibukanya MAPK adalah upaya mengembalikan madrasah ke tujuan semula dengan beberapa penyempurnaan. MAPK juga dimaksudkan sebagai penyuplai utama mahasiswa dalam jenjang pendidikan tinggi Islam. Namun, jumlah MAPK yang sangat terbatas, dan tidak seimbang dengan jumlah Perguruan Tinggi Islam yang banyak, tujuan pendirian MAPK pun menjadi kurang maksimal. Kondisi madrasah yang dipandang sebagian masyarakat telah terjadi pergeseran keilmuan, ditanggapi dengan membentuk madrasah diniyah atau melestarikan lembaga pesantren sebagai tempat pendidikan keagamaan.

Memasuki tahun 90-an, kebijakan pemerintahan orde baru mengenai madrasah ditujukan secara penuh untuk membangun satu sistem pendidikan nasional yang utuh. Dengan satu sistem yang utuh dimaksudkan bahwa pendidikan nasional tidak hanya bergantung pada pendidikan jalur sekolah teapi juga memanfaatkan jalur luar sekolah. Dalam rangka mewujudkan tujuan ini, pemerintahan orde baru melakukan langkah konkrit berupa penyusunan Undang-Undang No. 2 Tahun 1989 tentang Sistem Pendidikan Nasional dan sekaligus menggantikan UU No. 4 Tahun 1950 jo. No. 12 Tahun 1954. Dalam konteks ini, penegasan definitive tentang madrasah diberikan melalui keputusan-keputusan yang lebih operasional dan dimasukkan dalam kategori pendidikan sekolah tanpa menghilangkan karakter keagamaannya. Melalui upaya ini dapat dikatakan bahwa madrasah berkembang secara terpadu dalam sistem pendidikan nasional (Maksum, 1999:132133).

Perkembangan tersebut, menurut Azra, membawa implikasi yang cukup mendasar bagi keberadaan madrasah. Madrasah yang semula dipandang sebagai institusi pendidikan keagamaan, sekarang ini, ia dapat mengklaim diri menjadi sekolah umum plus. Oleh karena itu, madrasah mendapatkan beban tambahan yang cukup 
berat, karena di samping harus memberikan kurikulum sekolah umum yang setingkat secara penuh, ia juga harus memberikan materi-materi esensial kesilamannya, yang selama ini telah diajarkan. Beratnya beban yang diemban oleh madrasah tersebut masih ditambah dengan rendahnya kualitas sumber-sumber daya pembelajaran (Anwar, 2010:48).

\section{Pesantren dan madrasah dalam politik pendidikan pada masa reformasi}

Sebelum masa reformasi bergulir, ketika pemerintah masih menerapkan kurikulum tahun 1994, pendidikan agama ditempatkan di seluruh jenjang pendidikan, menjadi mata pelajaran wajib sejak SD sampai Perguruan Tinggi. Dari sudut pendidikan agama, kurikulum tahun 1994 hanyalah penyempurnaan dan perubahanperubahan yang tidak mempengaruhi jumlah jam pelajaran dan karakter pendidikan keagamaan siswa, sebagaimana tahun-tahun sebelumnya. Sampai pada masa orde baru tumbang di tahun 1998, pendidikan di Indonesia masih menggunakan UU Pendidikan tahun 1989 dan kurikulum 1994. Tumbangnya rezim orde baru ini menggulirkan gagasan reformasi, yang salah satu agendanya adalah perubahan dan pembaruan dalam bidang pendidikan, sebagaimana yang menjadi tema kritik para pemerhati pendidikan.

Menurut Anwar (2010:49), pada masa reformasi ini telah terjadi perubahan dari sistem pemerintahan yang bercorak sentralistik menuju desentralistik. Hal ini ditandai dengan UU RI No. 22 Tahun 1999 tentang Pemerintah Daerah. Pasal 7 ayat (1) UU RI No. 22 Tahun 1999 menyatakan bahwa agama merupakan salah satu urusan yang tidak diselenggarakan oleh pemerintah daerah. Di sisi lain, pendidikan, menurut pasal 11 ayat (2) UU RI No. 22 Tahun 1999 merupakan urusan wajib yang menjadi kewenangan pemerintah daerah. Madrasah, yang menurut UU Sisdiknas No. 2 Tahun 1989 didefinisikan sebagai sekolah umum yang berciri khas Islam, dapat diperdebatkan, apakah ia bagian dari agama ataukah pendidikan.

Lebih lanjut Anwar mengatakan, bahwa pasal yang diperdebatkan tersebut ternyata dapat ditemukan solusinya bahwa 
lembaga pendidikan yang dimasukkan sebagai bagian dari agama adalah pesantren dan madrasah diniyah, sementara madrasah sebagai sekolah umum berciri khas Islam dimasukkan bagian dari pendidikan. Oleh karena itu, madrasah seharusnya diserahkan pengelolaannya kepada pemerintah daerah, sehingga berbagai kebijakan yang tidak adil antara lembaga pendidikan madrasah dan sekolah dapat diminimalisir, tidak seperti realita yang terjadi sampai kini di mana madrasah tersebut masih diselenggarakan oleh Departemen Agama. Sementara Departemen Agama dapa mengkonsentrasikan diri pengelolaan lembaga pendidikan keagamaan di atas. Dalam posisi demikian, menurut Husni Rahim, Departemen Agama dapat menghasilkan ulama yang sanggup menghadapi persoalan yang lebih komplek ketimbang persoalan yang kita hadapi dalam kehidupan ini (Anwar, 2010: 49-50).

Sebenarnya, pada masa pemerintahan Presiden Abdurrahman Wahid, pesantren telah mendapatkan beberapa kemudahan. Melalui SKB Dua Menteri Nomor $1 / \mathrm{U} / \mathrm{KB} / 2000$ dan Nomor MA/86/2000 para santri di pesantren salafiyah yang berusia 7-15 tahun yang mengikuti pendidikan Diniyah Awaliyah (tingkat dasar) dan Diniyah Wustho (tingkat lanjutan pertama), yang tidak sedang menempuh pendidikan pada SD/MI dan SLTP/MTs atau bukan pula tamatan keduanya, dapat diakui memiliki kemampuan yang setara dan kesempatan yang sama untuk melanjutkan belajar ke jenjang pendidikan yang lebih tinggi, bila pesantren tersebut menambah beberapa mata pelajaran umum minimal 3 mata pelajaran, yakni Bahasa Indonesia, Matematika dan IPA. STTB atau Ijazah yang dikeluarkan oleh pesantren penyelenggara program ini diakui oleh pemerintah setara dengan STTB SD/MI atau SLTP/MTs dan dapat dipergunakan untuk melanjutkan ke jenjang pendidikan yang lebih tinggi dengan syarat-syarat yang akan diatur oleh departemen terkait.

Namun tidak semua pesantren salafiyah mengikuti ketentuan SKB Dua Menteri di atas, sebagian mereka memilih tetap mempertahankan tradisinya. Sikap tidak mengikuti ini dapat disebabkan karena ketidaktahuan pihak pesantren itu sendiri, atau 
bisa juga karena kekhawatiran mereka akan hilangnya identitas salaf yang telah dipertahankan selama ini karena masuknya intervensi pemerintah terhadap kurikulum pesantren (Anwar, 2010: 48, 53).

Dengan demikian, sebenarnya pesantren dan madrasah diniyah sebagai sumber pendidikan dan pencerdasan masyarakat Indonesia yang sudah berurat berakar sejak sebelum kemerdekaan ternyata baru mendapatkan pengakuan secara yuridis pada era reformasi ini. Pengakuan tersebut sangaat jelas tertuang dalam Undang-Undang RI No. 20 Tahun 2003 tentang Sistem Pendidikan Nasional. Dalam undang-undang tersebut diakui kehadiran pendidikan keagamaan sebagai salah satu jenis pendidikan di samping pendidikan lainnya.

\section{Catatan Akhir}

Peran dan keberadaan pondok pesantren sebagai salah satu lembaga pendidikan asli Indonesia memang harus tetap dilestarikan dan diperhatikan perkembangannya, karena kehadiran pondok pesantren di tengah-tengah masyarakat adalah selain untuk memberdayakan masyarakat juga sebagai wadah untuk menyiapkan kader-kader Ulama yang mampu menguasai dan memahami alQur'an dan Hadis secara baik dan benar dan sesuai dengan kebutuhan masyarakat.

Kemunculan madrasah dipandang menjadi salah satu indikator penting bagi perkembangan positif kemajuan prestasi budaya umat Islam, mengingat realitas pendidikan, sebagaimana terlihat pada fenomena madrasah yang sedemikian maju saat itu, adalah cerminan dari keunggulan capaian keilmuan, intelektual dan kultural. oleh karenanya timbul kebanggaan terhadap madrasah, karena lembaga ini mempunyai citra "eksklusif" dalam penilaian masyarakat.

Pesantren dan madrasah mengalami perkembangan pada masa orde baru dan reformasi dengan dikeluarkannya beberapa peraturan perundang-undangan yang mengatur pelaksanaan pendidikan umum dan pesantren secara setara (upaya menghilangkan dualisme pendidikan) 
E1-HiKMAH, Volume 8, Nomor 2, Desember 2014

\section{Daftar Pustaka}

Anwar, Ali. Pembaruan Pendidikan di Pesantren Lirboyo Kediri. Yogyakarta: Pustaka Pelajar, 2010).

Azra, Azyumardi. Pendidikan Islam; Tradisi dan Modernisasi Menuju Milenium Baru. Ciputat: Logos, 2002.

Daulay, Haidar Putra .Historitas dan Eksistensi Pesantren Sekolah dan Madrasah. (Yogyakarta: Tiara Wacana, 2001

Daulay, Haidar Putra. Pendidikan Islam, Dalam Sistem Pendidikan Nasional Indonesia . Jakarta: Kencana, 2004.

Daulay,Haidar Putra. Sejarah Pertumbuhan dan Pembaruan Pendidikan Islam di Indonesia. Jakarta: Kencana, 2007.

Haedari, M. Amin, dkk., Masa Depan Pesantren; dalam Tantangan Modernitas dan Tantangan Kompleksitas Global. Cet. I; Jakarta: IRD Press, 2004.

Hasbullah. Sejarah Pendidikan Islam di Indonesia; Lintasan Sejarah Pertumbuban dan Perkembangan . Cet. IV; Jakarta: RajaGrafindo Persada, 1995.

Madjid, Nurcholish. Bilik-bilik Pesantren; Sebuah Potret Perjalanan . Jakarta: Dian Rakyat, 1997.

Maksum. Madrash; Sejarah dan Perkembangannya. Jakarta: Logos Wacana Ilmu, 1999.

Mastuhu. Dinamika Sistem Pendidikan Pesantren; Suatu Kajian tentang Unsur dan Nilai Sistem Pendidikan Pesantren. Jakarta: INIS, 1994.

Nasir, M. Ridlwan. Mencari Tipologi Format Pendidikan Ideal; Pondok Pesantren di Tengah Arus Perubahan. Cet. I; Yogyakarta: Pustaka Pelajar 2005.

Qomar, Mujamil. Pesantren; dari Transformasi Metodologi Menuju Demokeratisasi institusi. Jakarta: Penerbit Erlangga, t.th.

Raharjo, M. Dawam. "Perkembangan Masyarakat dalam Perspektif Pesantren”, Pengantar dalam M. Dawam Raharjo (ed.), Pergaulan Dunia Pesantren: Membangun dari Bawah. Jakarta : P3M, 1985.

Steenbrink, Karel. A. Pesantren Madrasah Sekolah Pendidikan Islam dalam Kurun Modern. Jakarta : LP3ES, 1994. 
Wahid, Abddurrahman. Pondok Pesantren Masa Depan . Bandung: Pustaka Hidayah, 1999.

Yunus, Mahmud. Sejarah Pendidikan Islam di Indonesia . Jakarta: Hidakarya Agung, 1996.

Zuhairini, dkk. Sejarah Pendidikan Islam. Jakarta: Bumi Aksara, 1997. Zulhanda, "Pola dan Kebijakan Pendidikan Islam pada Masa Awal Kemerdekaan Sampai pada Orde Lama ", dalam Samsul Nizar, ed., Sejarah Pendidikan Islam; Menelusuri Jejak Sejarah Pendidikan Era Rasullah Sampai Indonesia. Cet. V; Jakarta: Kencana, 2013. 